International Journal of Biology, Pharmacy and Allied Seiences (IJBPAS) 'A Bridge Betusen caboratory and Qender'

WwW.ijbpas.com

\title{
PHYTOCHEMICAL SCREENING AND STANDARDIZATION OF PUSHPA VARTI (A POLYHERBAL AYURVEDIC OPHTHALMIC FORMULATION) THROUGH HPTLC
}

\section{SHIVKANT SHARMA ${ }^{1}$, RAJEEV G. DOLE ${ }^{2}$}

1: PhD Scholar, Department of Shalakya Tantra, Parul Institute of Ayurved, Parul

$$
\text { University, Vadodara, Gujarat }
$$

2: Professor, Department of Shalakya Tantra, Parul Institute of Ayurved, Parul Institute of Ayurved, Parul University, Vadodara, Gujarat

*Corresponding Author: Shivkant Sharma; E Mail: shivkants@ymail.com

Received $3^{\text {rd }}$ Oct. 2021; Revised $11^{\text {th }}$ Nov. 2021; Accepted $20^{\text {th }}$ Dec. 2021; Available online 25 ${ }^{\text {th }}$ Jan. $_{2022}$

\section{https://doi.org/10.31032/ijbpas/2022/11.1.2054}

\begin{abstract}
Many of the ophthalmic herbal formulations are described in classical literatures of Ayurvedathe traditional Indian system of medicine, as local applications in the form of vartis (Pills), anjana (Collyrium), and eye drops etc. These formulations are very effective in the management of eye diseases. Pushpavarti is a herbal ophthalmic formulation. It is used in the various eye aliments like refractive errors, presbiopia, pterygium, cysts, scar, subconjunctival hemorrhage and any growth in conjunctiva's in the form of anjana (Collyrium). Pushpavarti constitutes four drugs (dried flower of Sesamum indicum, and Jasminum grandiflorum and dried fruit of piper longum and piper nigrum). The present study was aimed to screen the organoleptic analysis, physico-chemical analysis, microbial test limit and phytochemical constituents through preliminary phytochemical tests of Pushpa Varti and to standardize this poly herbal mixture through High Performance Thin Layer Chromatography fingerprinting. The preliminary phytochemical screening of the extract revealed the presence of bioactive compounds like alkaloid, Tannins and polyphenols, saponins, flavonoids, steroids and Terpenoids. The HPTLC
\end{abstract}


fingerprint profile, obtained from this study, of the same herbal formulation may be used for authenticity and quality analysis.

Keywords: Ayurveda, Bioactive compounds, Pushpa Varti, Polyherbal formulation, Phytochemical analyses, HPTLC fingerprinting, standardization

\section{INTRODUCTION}

Ayurveda consists of well-organized knowledge of medicine being practiced for thousands of years and it possess its own library of valuable herbomineral formulations. These medicinal plants are rich sources of beneficial constituents and it is believed in Ayurveda that complex diseases can be treated with combination of medicinal plants rather than single $\operatorname{drug}^{[1]}$. Majority of the remedies arebased on plants and plants products along with minerals as well as animals origin. These medicine systems also described some formulations as local application in the form of vartis, anjana, eye drops etc.These generally improve the resistance, immunity, strengthen the organ or system and alleviate the ailments [2]. Tila (sesamum indicum) ${ }^{[3]}$, Pippali(piper longum) [4], Jati (Jasminum grandiflorum) ${ }^{[5]}$ and Maricha(piper nigrum) ${ }^{[6]}$ are such medicinal plants having various medicinal properties and used to treat various diseases. In this Marichai.e. proportional mixture of useful parts (Table 1) of these four herbs is used for preliminary phytochemical screening and standardization through High Performance Thin Layer Chromatography (HPTLC). In the present studyan effort has been made to determine the phytochemical constituents of "Pushpavarti" as well as to standardize this particular formulation which will provide another useful resource for future acceptance at global level.

\section{MATERIALS AND METHODS}

\section{Plant material}

The ingredients (Table 1) were procured from the local market and herbal gardens of Parul Institute of Ayurved. The collected drugs were identified and authenticated at the teaching pharmacy of Department of Dravyaguna, Parul Institute of Ayurved, Limda, Waghodia, Vadodara.

Methodology of preparation of Pushpa Varti [7] study Extract of Tila, Pippali, Jati and

Table 1: Ingredients (Plant materials)

\begin{tabular}{|c|c|c|c|c|}
\hline Sl. No. & Ingredients & Latin Name & Part Used & Quantity \\
\hline 1 & TilaPushpa & Sesamumindicum & Flower & 5 part \\
\hline 2 & Pippali & Piper longum & Fruit (inner part) & part \\
\hline 3 & Jati & Jasminum grandiflorum & Flower & 3 part \\
\hline 4 & Maricha & Piper nigrum & Fruit & 1 part \\
\hline
\end{tabular}


Pushpavarti was prepared at GMP Certified-

Parul Ayurved Pharmacy, Parul University, Limda, Vadodara, Gujarat. The Flowers of Tila (sesamum indicum), outer layer of fruits of Pippali (piper longum) were peeled and grains(inner part of Fruit) of Pippali (piper longum) were collected, flowers of Jati (Jasminum grandiflorum), fruit of Maricha (piper nigrum) were collected. These ingredients were taken in proportions $(5: 4: 3: 1)$ in sequence and dried. After drying these drugs weremade into fine powdered form and mixed well. They were mixed with water (with bhavanadravyas of the above drugs). Then these were made into a nice fine paste, rolled into small pills (Varti) and dried. This obtained drug "Pushpa Varti" was stored in a closed vessel and stored as accelerated stability study under (Temperature $40^{+} /-2{ }^{0} \mathrm{C}$ and $75^{+} /-5 \% \mathrm{RH}$ ) at Vasu Research Centre, Makarpura, Vadodara-390010, for furthur use.

\section{Phytochemical analysis}

Preliminary phytochemical screening and phytochemical studies through HPTLC were carried out at Vasu Research Centre, Makarpura, Vadodara-390010, Gujarat, India as per the standard procedures.

Preliminary phytochemical tests $[8,9]$
The preliminary phytochemical screening was performed according to the standard procedure. The procedures are as follows:

\section{Test for alkaloids}

Wagner's test: About $1 \mathrm{ml}$ of extract and $1 \mathrm{ml}$ of Wagner's reagent (dilute iodine solution) are added and mixed. Formation of reddish-brown precipitates indicates the presence of alkaloids.

\section{Dragendroff's Test}

To a few milligrams of extract dissolved in alcohol, a few drops of acetic acid and dragendroff's reagent were added and shaken well. An orange red precipitate formed indicates the presence of alkaloids.

\section{Mayer's Test}

To a few milligrams of extract dissolved in acetic acid, a few drops of mayer's reagent was added. A dull white precipitate formed indicates the presence of alkaloids.

\section{Hager's Test}

To a few milligrams of extract dissolved in acetic acid, $3 \mathrm{ml}$ of hager's reagent was added, the formation of yellow precipitate indicates the presence of alkaloids.

\section{Test for carbohydrates}

\section{Molisch's Test}

To the extract, $1 \mathrm{ml}$ of $\alpha$-naphthol solution and conc. sulphuric acid were added along the sides of test tube. Violet colour formed at 
the junction of the two liquids indicates the presence of carbohydrates.

\section{Fehling's Test}

A few milligrams of extract were mixed with equal quantities of Fehling's solution $\mathrm{A}$ and B. The mixture was warmed on a water bath. The formation of a brick red precipitate indicates the presence of carbohydrates.

\section{Benedict's Test}

To $5 \mathrm{ml}$ of Benedict's reagent, a few milligrams of extract was added, and boiled for two minutes and cooled. Formation of a red precipitate indicates the presence of carbohydrates

\section{Test for steroids}

\section{Libermann Burchard Test}

To the extract dissolved in choloro form, 1 $\mathrm{ml}$ of acetic acid and $1 \mathrm{ml}$ of acetic anhydride were added, then heated on a water bath and cooled. Few drops of con.H2SO4 were added along the sides of the test tube. Appearance of bluish green color indicates the presence of steroids.

\section{Salkowski Test}

The extract was dissolved in chloroform and equal volume of con. $\mathrm{H}_{2} \mathrm{SO}_{4}$ was added. Formation of bluish red to cheery red colour in chloroform layer and green fluorescence in the acid layer indicates the presence of steroids.

\section{Test for Saponins}

To a few milligrams of extract, distilled water was added and shaken. Stable froth formation indicates the presence of saponin.

\section{Test for Tannin}

To the extract a few drops of dilute solution of ferric chloride was added, formation of dark blue colour shows the presence of tannins.

\section{Test for Flavonoids}

Shinoda's test: To the extract in alcohol, a few magnesium turnings and few drops of conc. $\mathrm{H}_{2} \mathrm{SO}_{4}$ were added and heated on a water bath. Formation of red red to pink colour indicates the presence of flavonoids.

\section{Test for Phenol}

To the extract in alcohol, added two drops of alcoholic ferric chloride. Formation of blue to blue black indicates the presence of phenol.

\section{Test for Coumarins}

To the extract in alcohol, a few drops of $2 \mathrm{~N}$ sodium hydroxide solution was added. Dark yellow colour formation indicates the presence of coumarins.

\section{Test for Triterpenoids}

The extract was warmed with tin bits and few drops of thionyl chloride. Formation of pink colour indicates the presence of triterpenoids. 


\section{Test for Carboxylic Acid}

Extract dissolved in water is treated with sodium bicarbonate. Brisk effervescence indicates the presence of carboxylic acid.

\section{Test for resin}

Few milligrams of the sample was mixed with water and acetone. Turbidity indicates the presence of resin.

\section{Test for quinine}

A few milligrams of alcohol extract was treated with $0.5 \%$ of sodium hydroxide. Deep colouration like pink, purple or red indicates the presence of quinine.

\section{High Performance Thin Layer Chromatography $[10,11]$}

\section{Preparation of Test Solution}

$2.5 \mathrm{~g}$ of sample is weighed in an Iodine Flask and to it $50 \mathrm{ml}$ of Methanol is added. Vortex the iodine flask for 1 hour to dissolve the sample. Then the sample is filtered through Whatman Filter Paper which further filtered with syringe filter and the filterate of the sample is taken. The filterate thus obtainedwas used for HPTLC fingerprinting.

Preparation of Spray reagent [Anisaldehyde - sulphuric acid reagent]

$0.5 \mathrm{~mL}$ Anisaldehyde is mixed with $10 \mathrm{~mL}$ Glacial acetic acid, followed by $85 \mathrm{~mL}$ Methanol and $5 \mathrm{~mL}$ Sulphuric acid (98\%). $10.0 \mu \mathrm{l}$ of the above extract were applied on a pre-coated Silica gel $60 \mathrm{~F}_{254}$ on aluminum sheets to a band width of $10 \mathrm{~mm}$ using CAMAGLinomat 5 TLC applicator. The plate was developed in Toluene: Ethyl acetate: Acetic acid (7: 2:1 v/v/v ). The developed plates were visualized in short UV 254, 366, and then derivatised with Anisaldehyde Sulphuric acid reagent and scanned under UV 254nm, 366nm and 540nm. Rf and densitometric scan were recorded.

Table 2: Organoleptic and Physico-Chemical Analysis of Pushpa Varti

\begin{tabular}{|c|c|c|}
\hline Sr. No. & Parameters & Results \\
\hline 1 & Description & Crown coloured \\
\hline 2 & Odour & $\mathbf{1 2 4 . 5}$ mg \\
\hline 3 & Average weight & Smooth \\
\hline 4 & Touch & Hard \\
\hline 5 & Texture & $\mathbf{5 9}$ min \\
\hline 6 & Disintegration time & $\mathbf{6 . 7 8}$ \\
\hline
\end{tabular}


Table 3: Phytochemical constituents of PushpaVarti

\begin{tabular}{|c|c|c|}
\hline Sr. No. & Parameters & Results \\
\hline 1 & Alkaloid & + \\
\hline 2 & Starch & - \\
\hline 3 & Tannins and Polyphenols & + \\
\hline 4 & Saponins & + \\
\hline 5 & Flavonoids & ++ \\
\hline 6 & Carbohydrates & - \\
\hline 7 & Proteins & - \\
\hline $\mathbf{8}$ & Steroids & ++ \\
\hline 9 & Terpenoids & ++ \\
\hline 10 & Anthraquinine & - \\
\hline Key word: “+,,+++++ " indicates Present in increasing intensity and “ - " indicates Absent.
\end{tabular}

Table 4: Microbial Limit Test

\begin{tabular}{|c|c|c|}
\hline Sr. No. & Parameters & Result \\
\hline 1 & Total Yeast \& Mould Count & Absent \\
\hline 2 & Staphylococcus aureus & Absent \\
\hline 3 & Salmonella sp. & Absent \\
\hline 4 & Pseudomonas aeruginosa & Absent \\
\hline 5 & Escherichia coli & Absent \\
\hline
\end{tabular}

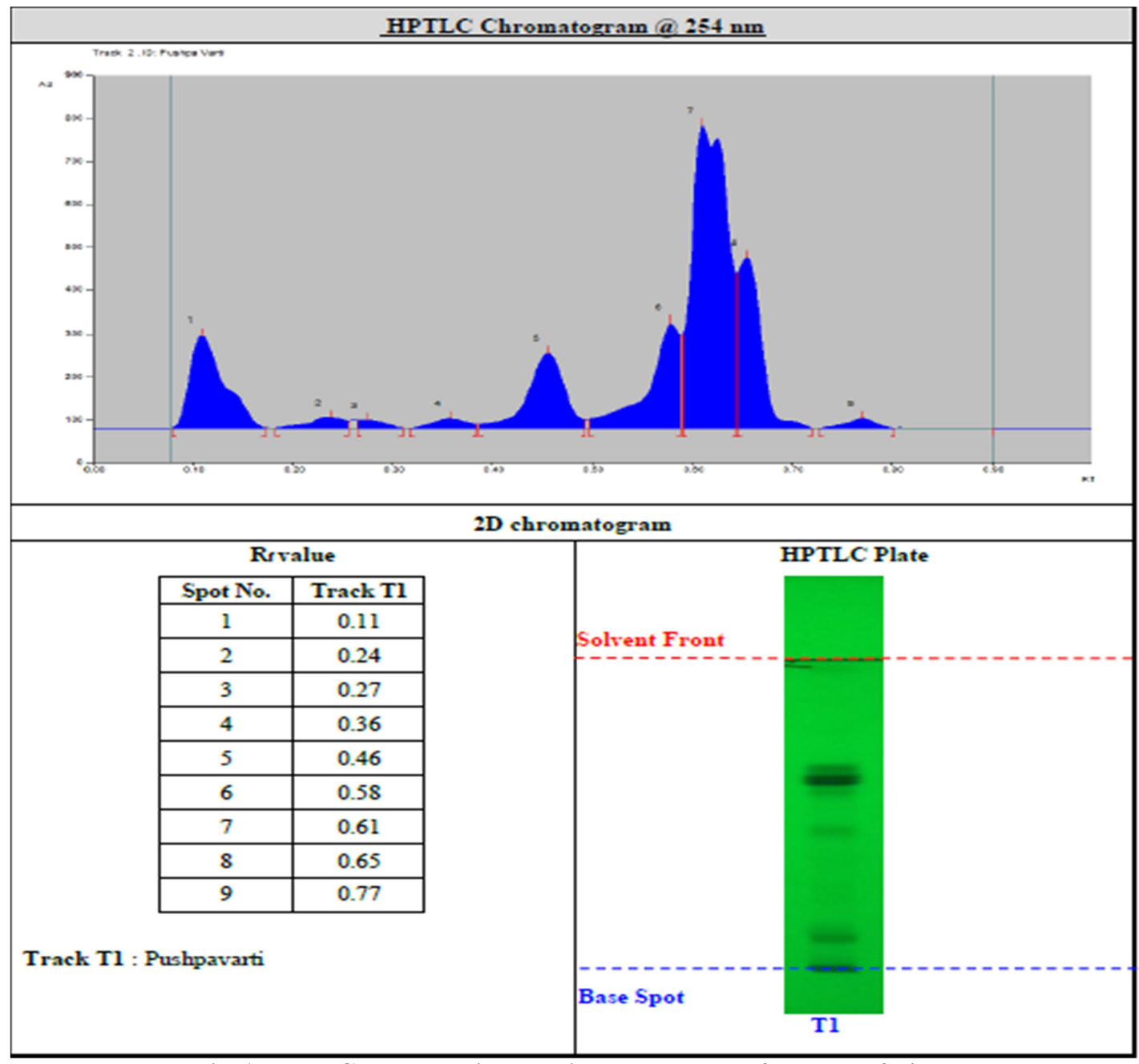

Fig. 1: HPTLC plate showing banding pattern and Rf Values at 254 nm 


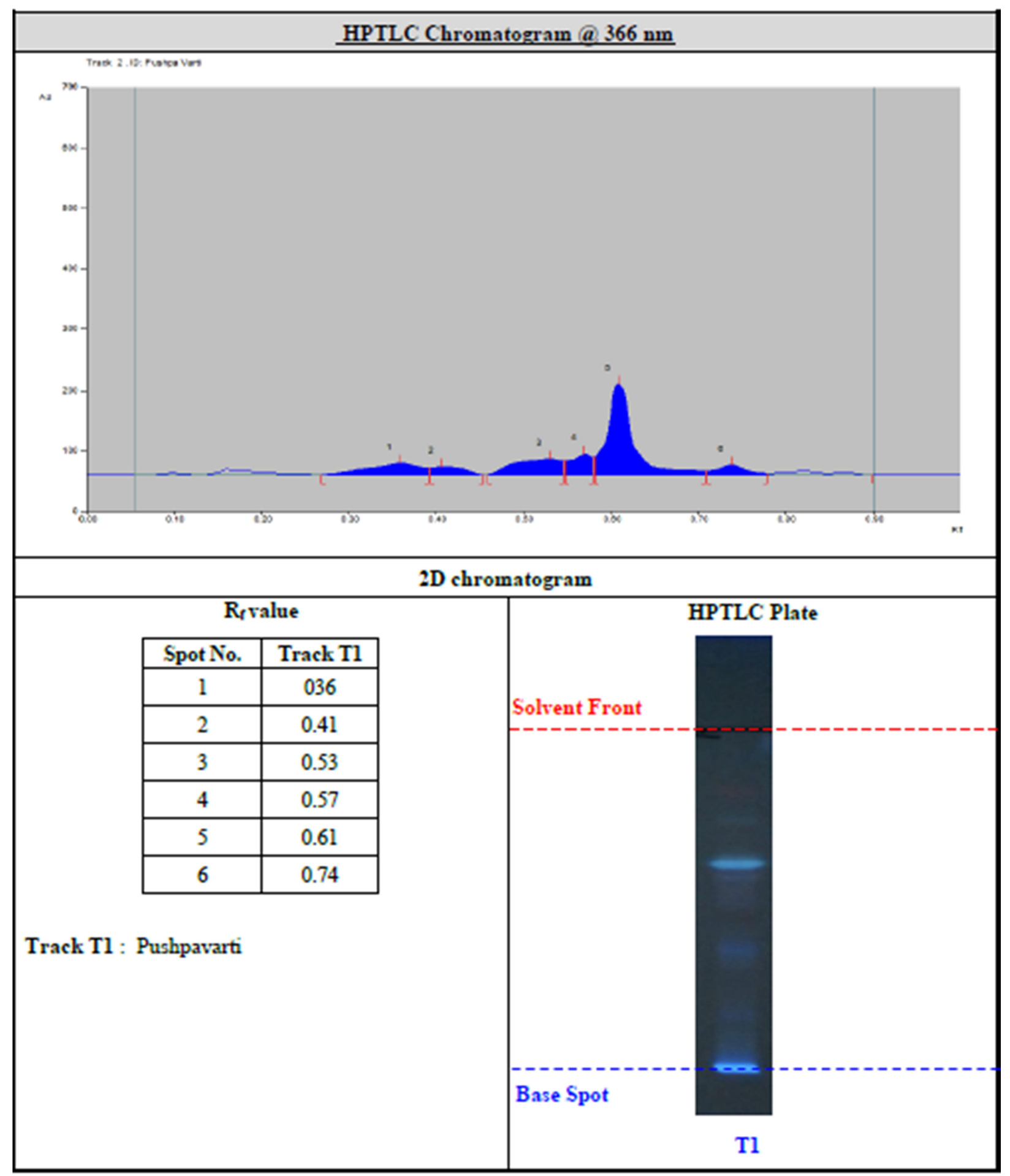

Fig. 2: HPTLC plate showing banding pattern and Rf Values at 366 n 


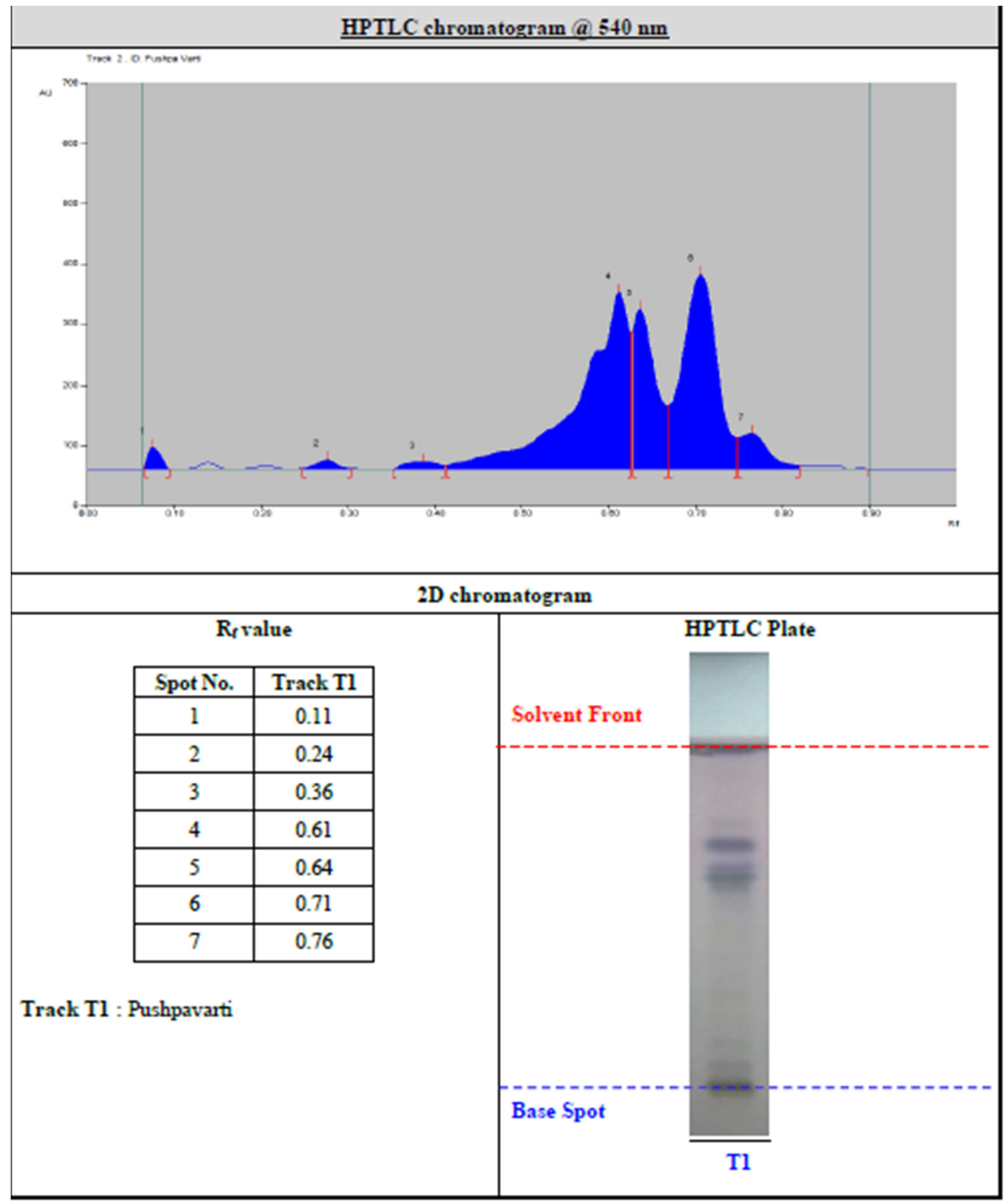

Fig. 3: HPTLC plate showing banding pattern and Rf Values at $540 \mathrm{~nm}$ 


\section{RESULTS AND DISCUSSION}

\section{Organoleptic and Physico-chemical}

Analysis:

Organoleptic and Physico-chemical characters of Pushpavarti are illustrated in (Table 2). The description provides as brown coloured Varti (Pills) having hard texture and smooth in touch. The obtained drug have characteristic odour with average weight as $124.5 \mathrm{mg}$ and disintegration time of 59 minutes with $\mathrm{pH}$ value as 6.78 .

\section{Preliminary Phytochemical Tests:}

The phytochemical screening results showed the presence of alkaloids, Tannins and polyphenols, saponins, flavonoids , steroids and Terpenoids in the extract of drugs of "Pushpavarti" (Table 3). Most of the identified phytochemical compounds have been reported to have various biological activities viz. the alkaloids possess antiinflammatory, antioxidant properties; Antispasmodic ,benefit in eye irritations, decongestant and diuretic ${ }^{[12]}$, Polyphenols possess antioxidant properties, useful in retinal degenerative diseases of eyes, improve the stability, expression, regeneration and folding of rhodopsin, It improve the integration of the receptor into the cell membrane while acting against oxidative stress at the same time. The neuroprotective effect on the retina observed in flavonoids may be associated with its modulating effects on specific cellular pathways related to antioxidant mechanisms , polyphenols may have a direct role on receptors, like in the case of Rhodopsin ${ }^{[13]}$. Saponins are natural antioxidant and antiinflammatory drugs, It has hemolytic properties ${ }^{[14,15]}$. Flavonoids improve microvascular functions, reduce intraocular hypertension and increase ocular blood flow, Flavonoids within the fruits and vegetables may operate in the prevention of both agerelated and diabetic cataract via multiple mechanisms including lowering oxidative stress, Flavonoids showed some protection against cataract formation, Flavonoids acts as antioxidant, anti-inflammatory and antiangiogenic mechanisms to stabilize collagen and to improve microvascular integrity, may aid in restoring proper RPE (retinal pigment epithelium) functions. Flavonoids demonstrate antioxidant properties and diminish oxidative damage to the lens of the eye. It can function in the eye to stabilize collagen and improve microvascular integrity, both important to slowing retinopathies and development of glaucoma. Flavonoids have anti-angiogenic. Diets high in flavonoid-rich fruits and vegetables have been shown to lower risk of vision disorders, including diabetic retinopathy, glaucoma, 
and cataracts. Flavonoids are bioavailable to the eye in quantities that can affect signal transduction mechanisms and thus could affect gene regulation and enzyme function within the eyes ${ }^{[16]}$. Steroids are antiinflammatory agents and has better chance of visual improvement with early diagnosis of visual $\operatorname{loss}^{[17]}$. Terpenoidsis source of potential geroprotectors, that can effectively influence the mechanisms of aging and agerelated diseases.Ithasanti-inflammatory properties andantioxidant activity which haseffects on stress-resistance on eyes. ${ }^{[18]}$

\section{High Performance Thin Layer}

\section{Chromatography:}

HPTLC photo documentation of Pushpavarti

(Fig -1) showed Nine, Six and Seven spots under $254 \mathrm{~nm}, 366 \mathrm{~nm}$ and $540 \mathrm{~nm}$ after derivatization respectively. Spot with $\mathrm{Rf}$ value 0.11 and 0.24 , were commonly detected in any two detection methods. Spot with Rf value 0.36 and 0.61 , were commonly detected in all three detection methods. All the three methods gave optimum separation of different bands and hence all of them may be used as HPTLC fingerprint pattern to identify the composition of the mixture (Fig. 1,2,3). Densitometric scan at $254 \mathrm{~nm}$ revealed 5 high peak and 4 peaks corresponding to 9 different compounds in the ethanol extract, compounds with Rf value
$0.11,0.46,0.58,0.61$ and 0.65 were the high peaks (Fig- 2). At $366 \mathrm{~nm}$ there was one high peak, with Rf value 0.61 , being the major peak detected (Fig- 2). At $540 \mathrm{~nm}$ there were seven peaks and three high peaks, with $\mathrm{Rf}$ value $0.61,0.64$ and 0.71 being the major peaks detected (Fig- 3).

\section{Microbial Limit Test}

While evaluating the microbial limit test, the total yeast and mould count, Staphylococcus aureus, Salmonellasp, Pseudomonas aeruginosa and Escherichia coliwere found absent. (Table 4)

\section{CONCLUSION}

Preliminary phytochemical tests of the extract of Pushpavart showed the presence of alkaloids, tannins and polyphenols, saponins, flavonoids, steroids and terpenoids. Phenols, which are reportedly bioactive in nature and may add up to the therapeutic effect of this polyherbal drug. HPTLC fingerprint profile of the same polyherbal formulation may be used for authentication and quality control. So it can be concluded that these parameters can be used for the evaluation of Pushpavarti. The present study can serve as the reference for the future works on Pushpavarti.

Conflict of interest: None Declared.

Financial Support: None 


\section{REFERENCES}

[1] Vaidya AD, Devasagayam TP. Current status of herbal drugs in India: an overview. Journal of clinical biochemistry and nutrition, 2007:41(1):111. https://doi.org/10.3164/jcbn.2007001

[2] Varun B. Gupta, Pharmacognostical and physicochemical analysis of pathyadivarti - A polyherbalayurvedic formulation, Int. J. of Pharm. \& Life Sci. (IJPLS), Vol. 3, Issue 4: April: 2012, 1643-1649

[3] Sharma PV. Chakhsusyadi Varga. In Dravyaguna Vijnana Varanasi: Chaukhambha Bharati Academy, 2006: 2: 120-123.

[4] Sharma PV. Chedanadi (Shleshmahara) Varga. In Dravyaguna Vijnana Varanasi: Chaukhambha Bharati Academy, 2006: 2: 275-279.

[5] Sharma PV. Chakhsusyadi Varga. In Dravyaguna Vijnana Varanasi: Chaukhambha Bharati Academy, 2006: 2: 178-180.

[6] Sharma PV. Deepanadi Varga. In Dravyaguna Vijnana Varanasi: Chaukhambha Bharati Academy, 2006: 2: 362-365.

[7] Prof. K.R. Srikantha Murthy, Shaerangdhara- Samhita, Uttar khanda 13/82-84 (Netra PrasadanVidhi) Adhyaya, Chapter 13/82-84.
[8] Brain KR, Turner T. The practical evaluation of Phytopharmaceuticals. Bristol: Wright-Scientechnica, 1975, 10 12

[9] Harborne JB. Method of extraction and isolation in Phyto chemical methods. $2^{\text {nd }}$ ed., London: Chapman and Hall, 1998, 60-66.

[10] Sethi PD. High Performance Thin Layer Chromatography. $1^{\text {st }}$ ed., New Delhi: CBS Publishers and Distributors, 1996, $1-56$.

[11] Stahl I. Thin layer Chromatography, a laboratory hand book. Berlin: SpringerVerlag, 1969: 127(8): 52-86.

[12] Michael Heinrich, Jeffrey Mah, Alkaloids Used as Medicines: Structural Phytochemistry Meets Biodiversity-An Update and Forward Look Published online $2021 \quad$ Mar 25. doi: 10.3390/molecules26071836.

[13]Pol Fernandez-Gonzalez, Polyphenols and Visual Health: Potential Effects on Degenerative Retinal Diseases, Published online 2021 Jun 4. doi: 10.3390/molecules26113407 Page 1

[14] Shahira M. Ezzat, Preparation of Phytopharmaceuticals for the Management of Disorders, Chapter 7 Herbal cosmeticology, Pages 129-168 
[15] G.P. Savage, in Encyclopedia of Food and Health, 2016, Pages 714-716

[16] Paul E. Milbury, Journal of Nutrition in Gerontology and Geriatrics 31(3):25468, July 2012,Source- PubMed page (254-264)

[17]Peter J. Barnes, Anti-inflammatory actions of steroids: molecular mechanisms, ClinSci (Lond) (1998) 94(6): 557-572

[18]Ekaterina Proshkina, Antioxidants 2020, 9(6), 529; https://doi.org/10.3390/antiox90605 29, Published: 17 June 2020, Page-1-50. 